Sains Malaysiana 47(1)(2018): 91-97

http://dx.doi.org/10.17576/jsm-2018-4701-11

\title{
Characterization and Screening of Lipolytic Bacteria from Thai Fermented Fish
}

(Pencirian dan Penyaringan Bakteria Lipolitik daripada Ikan Pekasam Thai)

\author{
Rungsima DaroonPunt, NAOTO TANAKA, MASATAKa UCHINO \& SOMBOON TANASUPAWAT*
}

\section{ABSTRACT}

Nine bacterial strains were isolated from Thai fermented fish by the standard dilution technique using JCM no. 377 medium. The rod shaped isolate FN2-3 was identified as Virgibacillus dokdonensis while isolates FN2-3 and FN6-6 as V. halodenitrificans, FN1-13 as Corynebacterium variabile, FNl-10 as Oceanobacillus iheyensis and FN3-7 was Bacillus amyloliquefaciens subsp. plantarum. The coccal isolates, FN6-1 and FN6-7 were Staphylococcus saprophyticus subsp. bovis and FN6-8 was $\mathrm{S}$. saprophyticus subsp. saprophyticus, based on their phenotypic characteristics and 16S rRNA gene sequence analyses at a 99.63-100\% sequence similarity. Their lipase activity in complex medium (CM), CM medium with $1 \%(\mathrm{v} / \mathrm{v})$ Tween 20 or CM medium with $1 \%(\mathrm{v} / \mathrm{v})$ Tween 80 ranged from $1.12 \pm 0.03-3.77 \pm 0.04$ unit/mL, with the highest lipase activity found with V. dokdonensis FN1-8 cultivated with CM with 1\% (v/v) Tween 80.

Keywords: Fermented fish; halophilic bacteria; lipase; lipolytic bacteria

\section{ABSTRAK}

Sembilan strain bakteria telah dipencilkan daripada ikan pekasam Thai melalui teknik kecairan piawai yang menggunakan medium JCM no. 377. Pencilan berbentuk rod FN2-3 dikenal pasti sebagai Virgibacillus dokdonensis manakala pencilan FN2-3 dan FN6-6 sebagai V. Halodenitrificans, FN1-13 sebagai Corynebacterium variabile, FN1-10 sebagai Oceanobacillus iheyensis dan FN3-7 sebagai Bacillus amyloliquefaciens subsp. plantarum. Pencilan kokus FN6-1 dan FN6-7 adalah Staphylococcus saprophyticus subsp. bovis dan FN6-8 S. saprophyticus subsp. saprophyticus, berdasarkan ciri fenotip dan 16S rRNA analisis jujukan gen pada satu persamaan turutan 99.63-100\%. Aktiviti lipase mereka dalam medium kompleks (CM), medium CM 1\% (v/v) Tween 20 atau CM medium dengan 1\% (v/v) Tween 80 berjulat dari 1.12 \pm 0.03 $3.77 \pm 0.04$ unit/mL dengan aktiviti lipase tertinggi dilihat pada $\mathrm{V}$. dokdonensis FN1-8 yang ditanam dengan $1 \%(v / v)$ Tween 80 CM.

Kata kunci: Bakteria halofili lipase; bakteria lipolitik; ikan pekasam

\section{INTRODUCTION}

Lipases (Triacylglycerol acylhydrolase, EC 3.1.1.3) are serine hydrolases thatcatalyze the hydrolysis of triglycerides to diacylglycerides, monoglycerides and fatty acids under aqueous conditions (Ghasemi et al. 2011). They are of commercial importance given their wide usage in industry. Lipases are produced by microorganisms (bacteria and fungi), plants and animals . However, microbial lipases, especially from bacteria, are more useful than their plant and animal derivatives because of several important properties (Snellman et al. 2002). Many microorganisms in the genera Acinetobacter, Bacillus, Burkholderia, Idiomarina, Marinobacter, Natronococcus, Pseudomonas and Staphylococcus have been reported to produce lipase (Boutaiba et al. 2006; Gayathri et al. 2013; Li et al. 2014; Martin et al. 2003; Mrozik et al. 2006; Walavalkar \& Bapat 2001).

Bacterial lipases are used extensively in the food and dairy industry for the hydrolysis of milk fat, cheese ripening, flavor enhancement and lipolysis of butter fat and cream (Hasan et al. 2006). Lipases are also used in the detergent, textile, cosmetic, pulp and paper industries (Hasan et al. 2006; Sharma et al. 2001; Sirisha et al. 2010). In addition, these enzymes are used in the synthesis of biodiesel (Noureddini et al. 2005) and in the pharmaceutical industry (Higaki \& Morohashi 2003).

In Thailand, there are many kinds of fermented fish that are consumed daily, such as Nam-pla (fish sauce), Tai-pla (fermented fish entrails), Kee-dee (fermented three spot gourami fish (Trichopodus trichopterus) entrails), Koeypla (fish paste) and Pla-ra (fermented fish) (Tanasupawat \& Komagata 2001). Many microorganisms are found in fermented fish products that can produce extracellular lipases that catalyze the hydrolysis of triacylglycerols to glycerol and free fatty acids, including low molecular weight volatile fatty acids, such as acetic acid, propionic acid and butyric acid (Fukami et al. 2002). These later components are associated with the aroma and flavor in fermented fish products (Camacho et al. 2009). The aim of this research was to isolate, identify and screen the lipase activity of halophilic bacterial strains from Thai fermented fish products. 


\section{MATERIALS AND METHODS}

\section{SOURCES AND ISOLATION METHODS}

Four fermented fish samples, comprised of two Koeypla (Fish paste) samples collected from Mueang and Cha-uat district, Nakhon Si Thammarat province, one Kee-dee (Fermented three spot gouramifish (Trichopodus trichopterus) entrails) and one Tai-pla (Fermented fish entrails) sample collected from Mueang district, Nakhon Si Thammarat province, Thailand were used for the isolation of bacteria (Table 1). Bacterial strains were isolated by the spread plate technique using $1 \mathrm{~g}$ of the respective fermented fish sample diluted in $99 \mathrm{~mL} \mathrm{JCM}$ no. 377 medium solution. This was then 10 -fold serially diluted with JCM no. 377 medium solution and $0.1 \mathrm{~mL}$ of each dilution was spread per JCM no. 377 agar plate and incubated at $37^{\circ} \mathrm{C}$ for $48-72 \mathrm{~h}$. Colonies which showed a different appearance were pick up and then were transferred to JCM no. 377 slant.

\section{PRIMARY SCREENING OF LIPASE ACTIVITY}

All of the isolated halophilic bacteria were screened on lipolytic agar (Barrow \& Feltham 1993) composed of 1\% (w/v) peptone, $0.01 \%(\mathrm{w} / \mathrm{v}) \mathrm{CaCl}_{2} .2 \mathrm{H}_{2} \mathrm{O}, 2 \%(\mathrm{w} / \mathrm{v})$ agar and $1 \%(\mathrm{v} / \mathrm{v})$ of one of tributyrin, Tween 20, Tween 40, Tween 60 or Tween 80 supplemented with $5 \%$ (w/v) NaCl and incubated at $37^{\circ} \mathrm{C}$ for 3-7 days. Isolated halophilic bacteria colonies that showed an opaque zone around the colony (potentially positive for lipase activity) were selected for further study.

\section{DETERMINATION OF LIPASE ACTIVITY}

The selected isolates were cultivated in complex medium (CM; comprised of $(\mathrm{g} / \mathrm{L})$ : casein peptone 7.5 ; yeast extract 10.0 ; sodium citrate $3.0 ; \mathrm{MgSO}_{4} .7 \mathrm{H}_{2} \mathrm{O} 20.0$ and $\mathrm{KCl} 2.0 ; \mathrm{FeSO}_{4} .7 \mathrm{H}_{2} \mathrm{O} 0.01$; plus $5 \%(\mathrm{w} / \mathrm{v}) \mathrm{NaCl}$ $\mathrm{pH} 7.0$ ) for $48 \mathrm{~h}$ at $37^{\circ} \mathrm{C}$ for lipase production. The lipase activity was determined in the post-culture CM using $p$-nitrophenylpalmitate ( $p$-NPP) as the substrate according to Li et al. (2014), with some modifications. The substrate $p$-NPP was dissolved in 2-propanol and then mixed with $9 \mathrm{~mL}$ of Tris- $\mathrm{HCl}$ buffer $(10 \mathrm{mM}, \mathrm{pH} 8.0)$ to a final concentration of $1 \mathrm{mM}$. After pre-incubation for $5 \mathrm{~min}$, the reaction was initiated by the addition $0.5 \mathrm{~mL}$ of the appropriately diluted enzyme solution (cell free culture medium) to $0.5 \mathrm{~mL}$ of substrate solution, and incubated at $60^{\circ} \mathrm{C}$ for $1 \mathrm{~h}$. The reaction was then stopped by the addition of $1 \mathrm{~mL}$ of $\mathrm{NaHCO}_{3}$ solution $(0.1 \mathrm{M})$ and the amount of $p$-nitrophenol ( $p$-NP) released was determined from the absorbance at $405 \mathrm{~nm}$ against a blank. One unit (U) was defined as the amount of enzyme liberating $1 \mu \mathrm{mol}$ of $p$-NP per minute under the standard assay conditions.

\section{IDENTIFICATION METHODS}

\section{PHENOTYPIC CHARACTERIZATION}

The morphological and cultural characteristics were determined as previously described (Barrow \& Feltham 1993; Leifson 1963; Namwong 2005). The isolates were cultivated on JCM no. 377 agar plates containing 5\% $(\mathrm{w} / \mathrm{v}) \mathrm{NaCl}$ at $37^{\circ} \mathrm{C}$ for $2-3 \mathrm{~d}$ and then examined for the colony and cell characteristics, such as the color and shape of colonies and the shape, motility and Gram staining of the cells. Acid production from carbon sources was evaluated in marine oxidation-fermentation medium as described (Leifson 1963). The hydrolysis of gelatin, starch and arginine by each isolate was determined (Barrow $\&$ Feltham 1993), as was its ability to grow in different salinity $(0,1,3,5,7,10,15$ and $20 \%$ (w/v) NaCl), pH (49.5 , interval of 0.5$)$ and temperature $(20,25,30,40$ and $45^{\circ} \mathrm{C}$ ) levels.

TABLE 1. Source of isolation, province, isolate number, 16S rRNA gene sequence similarity (\%) and closest species

\begin{tabular}{|c|c|c|c|c|}
\hline Fermented fish & Province & Isolate no. & $\begin{array}{l}\text { Similarity } \\
(\%)\end{array}$ & Closest species \\
\hline \multirow[t]{3}{*}{ Fish paste (Koey-Pla) } & \multirow{3}{*}{$\begin{array}{l}\text { Mueang district, } \\
\text { Nakhon Si Thammarat }\end{array}$} & FN1-8 & 99.63 & Virgibacillus dokdonensis \\
\hline & & FN1-10 & 99.78 & Oceanobacillus iheyensis \\
\hline & & FN1-13 & 99.85 & Corynebacterium variabile \\
\hline Fish paste $($ Koey-Pla) & $\begin{array}{l}\text { Cha-uat district, } \\
\text { Nakhon Si Thammarat }\end{array}$ & FN2-3 & 99.86 & Virgibacillus halodenitrificans \\
\hline $\begin{array}{l}\text { Fermented three spot } \\
\text { gourami fish }(\text { Kee-Dee })\end{array}$ & $\begin{array}{l}\text { Mueang district, } \\
\text { Nakhon Si Thammarat }\end{array}$ & FN3-7 & 99.86 & Bacillus amyloliquefaciens subsp.plantarum \\
\hline \multirow{4}{*}{$\begin{array}{l}\text { Fermented fish entrails } \\
(\text { Tai-Pla })\end{array}$} & \multirow{4}{*}{$\begin{array}{l}\text { Mueang district, } \\
\text { Nakhon Si Thammarat }\end{array}$} & FN6-1 & 100 & Staphylococcus saprophyticus subsp. bovis \\
\hline & & FN6-6 & 99.86 & Virgibacillus halodenitrificans \\
\hline & & FN6-7 & 99.93 & Staphylococcus saprophyticus subsp. bovis \\
\hline & & FN6-8 & 99.93 & $\begin{array}{l}\text { Staphylococcus saprophyticus subsp. } \\
\text { saprophyticus }\end{array}$ \\
\hline
\end{tabular}




\section{GENOTYPIC CHARACTERIZATION}

The 16S rRNA gene fragment was amplified by polymerase chain reaction (PCR) as previously described (Yamada et al. 2000). The PCR products were resolved and checked by gel electrophoresis in comparison with a $1 \mathrm{~kb}$ DNA marker. The PCR products were sent to Macrogen, Korea for commercial sequencing using the 20F (5'-AGTTTGATCCTGGCTC-3') and 1492R (5'-TACGGYTACCTTGTTACGACTT-3') primers. The obtained sequences were checked for homology to known sequences using the standard BLASTn sequence similarity searching program from the web site http://eztaxon-e. ezbiocloud.net/ (Chun et al. 2007). Multiple alignments of the obtained sequences were performed with the BioEdit program. The neighbor-joining tree (Saitou \& Nei 1987) were then constructed using the MEGA 5.2 program (Tamura et al.2011), and the confidence value of branches of the phylogenetic tree was determined using the bootstrap analysis (Felsenstein 1981) based on 1,000 replications.

\section{RESULTS AND DISCUSSION}

Nine potentially different bacterial strains that produced extracellular lipase were isolated from four samples of fermented fish products, which included Koey-pla,Kee-dee and Tai-pla, collected from markets in Thailand (Table 1). These nine isolates (FN1-8, FN1-10, FN1-13, FN2-3, FN37, FN6-1, FN6-6, FN6-7 and FN6-8) showed opaque halos of calcium oleateon lipolytic agar when Tween was used (Garcia-Lepe et al. 1997), while they were all negative for the hydrolysis of tributyrin.

The isolates showed lipolytic activity in the culture medium when cultivated for $48 \mathrm{~h}$ at $37^{\circ} \mathrm{C}$ in $\mathrm{CM}(1.2 \pm$ $0.06-3.38 \pm 0.02 \mathrm{U} / \mathrm{mL}), \mathrm{CM}+1 \%(\mathrm{v} / \mathrm{v})$ Tween $20(1.12 \pm$ $0.03-2.67 \pm 0.05 \mathrm{U} / \mathrm{mL})$ and $\mathrm{CM}+1 \%(\mathrm{v} / \mathrm{v})$ Tween $80(1.26$ $\pm 0.02-3.77 \pm 0.04 \mathrm{U} / \mathrm{mL}$ ) (Figure 1). The highest lipase activity $(3.77 \pm 0.04 \mathrm{U} / \mathrm{mL})$ was obtained from the culture medium of isolate FN1-8 (identified as $V$. dokdonensis, see below) cultured with $1 \%(\mathrm{v} / \mathrm{v})$ Tween 80 . The high lipase activity is based on that Tween 80 that contained esters of oleic acid that are rarely cleaved by esterases, where as Tween 20 is easily hydrolyzed by esterases as it contains esters of lauric acid, a lower chain fatty acid (Kumar et al. 2012)

The nine isolated bacterial strains products were all Gram-positive bacteria and were divided into the five genera of Corynebacterium, Virgibacillus, Oceanobacillus and Bacillus for the seven rod-shaped isolates and Staphylococcus for the two coccal isolates based on their phenotypic characteristics and 16S rRNA gene sequence analysis (Tables 1 and 2). They grew at $25^{\circ} \mathrm{C}$ and in $0 \%$ $(\mathrm{w} / \mathrm{v}) \mathrm{NaCl}(\mathrm{w} / \mathrm{v})$, hydrolyzed Tween 40 but not tributyrin. Their differential phenotypic characteristics are presented in Table 2.

Isolate FN1-13 showed circular and cream colonies, grew in $15 \%(\mathrm{w} / \mathrm{v}) \mathrm{NaCl}, \mathrm{pH} 6-9$ and at $25-40^{\circ} \mathrm{C}$. Based on the $16 \mathrm{~S}$ rRNA gene sequence (1,373 bp), it was identified as C. variabile (Figure 2) from its $99.85 \%$ sequence similarity to C. variabile DSM $20132^{\mathrm{T}}$ (Collins 1987).

Isolate FN1-8 had circular to slightly irregular and milky white colonies, grew in $0-20 \%$ (w/v) NaCl, pH 6-9.5 and at $25-45^{\circ} \mathrm{C}$. Based on the $16 \mathrm{~S}$ rRNA gene sequence (1,373 bp), it was identified as $V$. dokdonensis (Figure 3) from its $99.63 \%$ sequence similarity to $V$. dokdonensis DSW- $10^{\mathrm{T}}$ (Yoon et al. 2005). Isolates FN2-3and FN6-6 had circular and cream colonies, grew in $0-20 \%(\mathrm{w} / \mathrm{v}) \mathrm{NaCl}$ (w/v), pH6-9.5 and pH6-9 and at $25-40^{\circ} \mathrm{C}$ and $25-45^{\circ} \mathrm{C}$, respectively. However, based on the $16 \mathrm{~S}$ rRNA gene sequence $(1,424$ and $1,406 \mathrm{bp}$, respectively), they were both identified as $V$. halodenitrificans (Figure 3 ) from their $99.86 \%$ sequence similarity to $V$. halodenitrificans DSM $10037^{\mathrm{T}}$ (Yoon et al. 2005). Similar to FN6-6, isolate FN110 also had circular and cream colonies, grew in $0-20 \%$ $\mathrm{NaCl}(\mathrm{w} / \mathrm{v}), \mathrm{pH} 6-9.5$ and at $25-40^{\circ} \mathrm{C}$, but based on the $16 \mathrm{~S}$ rRNA gene sequence $(1,390 \mathrm{bp})$, it was identified as $O$.

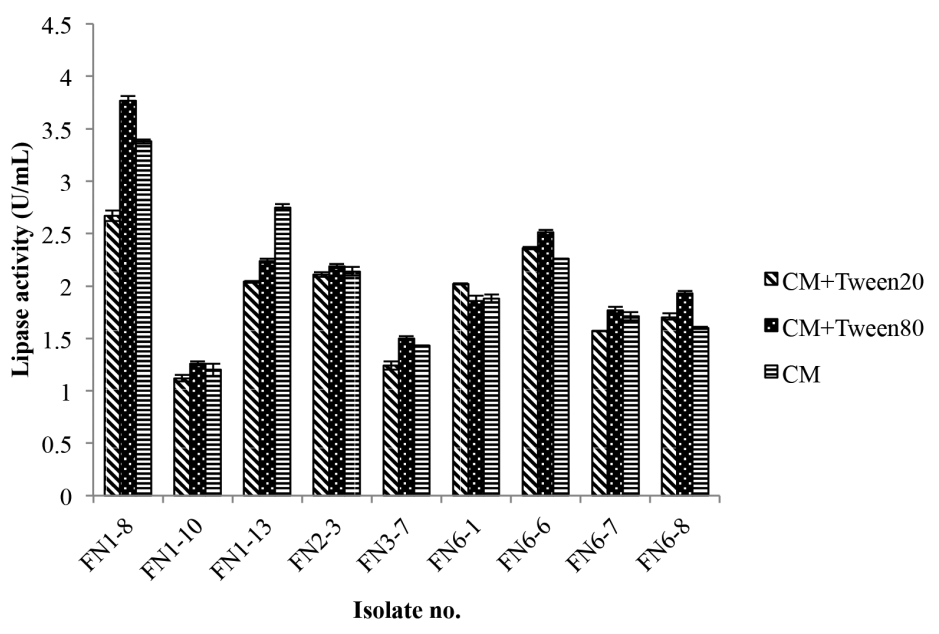

FIGURE 1. Lipase activity $(\mathrm{U} / \mathrm{mL})$ of isolates in $\mathrm{CM}$ medium, $\mathrm{CM}$ medium with $1 \%(\mathrm{v} / \mathrm{v})$ Tween 20 or CM medium with $1 \%$ (v/v) Tween 80 
TABLE 2. Differential phenotypic characteristics of the nine isolates

\begin{tabular}{|c|c|c|c|c|c|c|c|c|c|}
\hline Characteristic & FN1-13 & FN1-8 & FN2-3 & FN6-6 & FN1-10 & FN3-7 & FN6-8 & FN6-1 & FN6-7 \\
\hline Genera & $\mathrm{CB}$ & $\mathrm{V}$ & V & V & $\mathrm{O}$ & B & $\mathrm{S}$ & $\mathrm{S}$ & $\mathrm{S}$ \\
\hline Cell shape & $\mathrm{R}$ & $\mathrm{R}$ & $\mathrm{R}$ & $\mathrm{R}$ & $\mathrm{R}$ & $\mathrm{R}$ & $\mathrm{C}$ & $\mathrm{C}$ & $\mathrm{C}$ \\
\hline Pigmentation & $\mathrm{CR}$ & MW & $\mathrm{CR}$ & $\mathrm{CR}$ & $\mathrm{CR}$ & $\mathrm{CR}$ & PY & PY & PY \\
\hline \multicolumn{10}{|l|}{ Growth in: } \\
\hline pH 5.0 & - & - & - & - & - & + & - & + & - \\
\hline pH 9.5 & - & + & + & - & + & - & - & - & - \\
\hline $45^{\circ} \mathrm{C}$ & - & + & - & + & - & + & - & - & - \\
\hline $10 \%(\mathrm{w} / \mathrm{v}) \mathrm{NaCl}$ & + & + & + & + & + & + & + & - & - \\
\hline $15 \%(\mathrm{w} / \mathrm{v}) \mathrm{NaCl}$ & + & + & + & + & + & - & - & - & - \\
\hline $20 \%(\mathrm{w} / \mathrm{v}) \mathrm{NaCl}$ & - & + & + & + & + & - & - & - & - \\
\hline Nitrate reduction & - & - & + & + & - & - & - & + & + \\
\hline Arginine & + & + & - & - & - & + & - & - & + \\
\hline \multicolumn{10}{|l|}{ Hydrolysis of: } \\
\hline Tween 20 & + & $\mathrm{W}$ & $\mathrm{W}$ & $\mathrm{W}$ & $\mathrm{W}$ & + & $\mathrm{W}$ & $\mathrm{W}$ & $\mathrm{W}$ \\
\hline Tween 80 & $\mathrm{w}$ & $\mathrm{W}$ & + & $\mathrm{W}$ & $\mathrm{W}$ & + & $\mathrm{W}$ & $\mathrm{W}$ & $\mathrm{W}$ \\
\hline Gelatin & - & - & + & + & + & + & + & - & - \\
\hline Starch & - & - & - & - & - & + & - & - & - \\
\hline \multicolumn{10}{|l|}{ Acid from: } \\
\hline D-Arabinose & - & - & - & - & - & - & + & - & - \\
\hline D-Cellobiose & - & + & - & - & $\mathrm{W}$ & + & - & - & - \\
\hline D-Fructose & - & - & + & + & + & + & + & + & + \\
\hline D-Galactose & - & + & + & + & - & - & - & + & - \\
\hline D-Glucose & - & + & + & + & + & + & + & + & + \\
\hline Lactose & - & + & - & - & - & - & + & - & - \\
\hline Maltose & - & + & $\mathrm{W}$ & $\mathrm{W}$ & - & - & + & + & + \\
\hline D-Mannose & - & + & - & - & + & + & + & - & - \\
\hline D-Mannitol & - & - & + & + & + & + & + & + & + \\
\hline Sucrose & - & + & + & + & - & + & + & + & + \\
\hline D-Sorbitol & - & + & - & - & w & - & - & - & - \\
\hline D-Xylose & - & W & - & - & - & - & + & - & - \\
\hline
\end{tabular}

CB, Corynebacterium; V, Virgibacillus; O, Oceanobacillus; B, Bacillus; S, Staphylococcus; CR, cream; PY, pale yellow; MW, milky white; C, spherical cocci; R, rod-shaped; +, positive; - negative; w, weakly positive

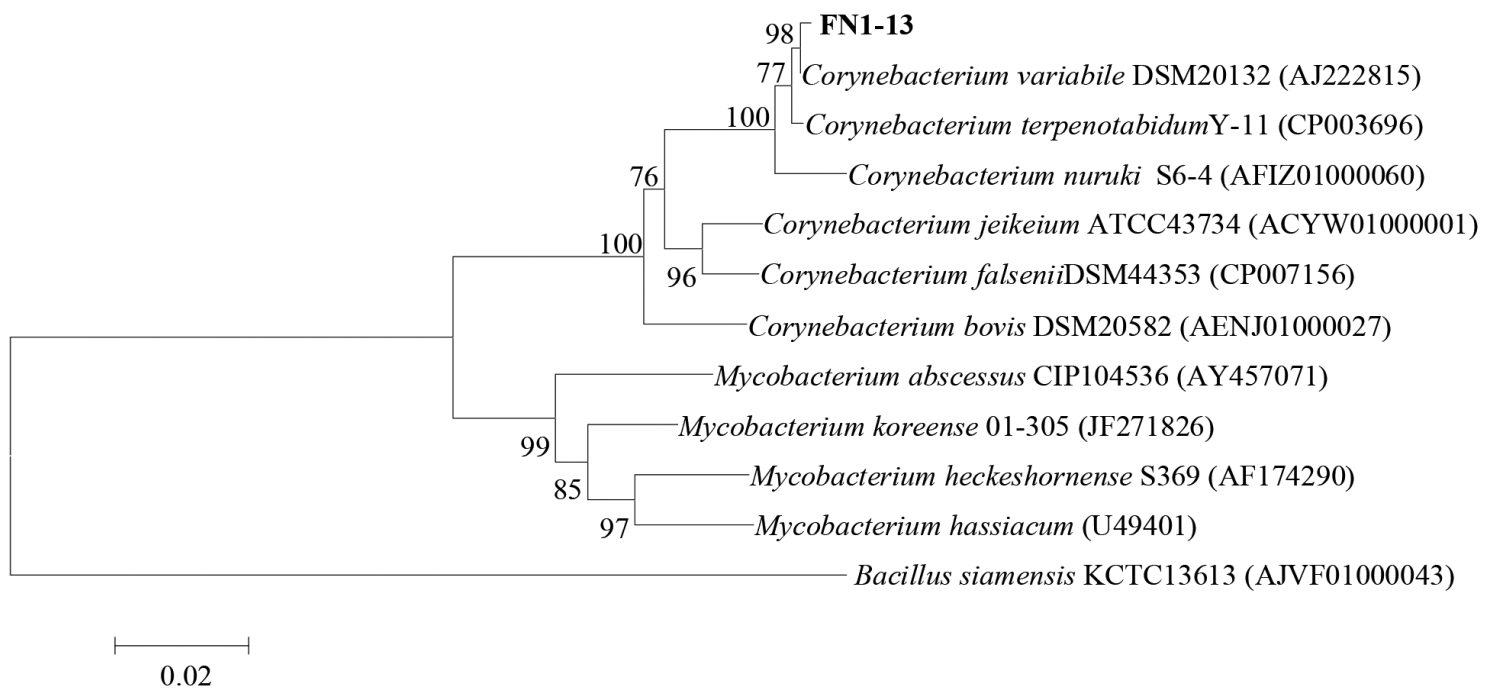

FIGURE 2. Neighbour-joining tree based on the 16S rRNA gene sequences showing relationships among Corynebacterium variabile FN1-13 isolate and related species. The numbers on the branches indicate the percentage bootstrap values of 1,000 replicates; only values $>50 \%$ are indicated. Bar, 0.02 substitutions per nucleotide position 
iheyensis (Figure 3) from its $99.78 \%$ sequence similarity to $O$. iheyensis HTE $831^{\mathrm{T}}$ (Lu et al. 2001).

Isolate FN3-7 had circular and cream colonies, but grew in $0-15 \% \mathrm{NaCl}(\mathrm{w} / \mathrm{v}), \mathrm{pH} 5-9$ and at $25-40^{\circ} \mathrm{C}$ and was identified as $B$. amyloliquefaciens subsp. plantarum based on its $99.79 \%$ 16S rRNA gene sequence $(1,436$ bp) similarity to $B$. amyloliquefaciens subsp. plantarum (Niazi et al. 2014). Isolate FN6-8 had circular and pale yellow colonies, grew in $0-10 \% \mathrm{NaCl}(\mathrm{w} / \mathrm{v}), \mathrm{pH} 6-9$ and at $25-40^{\circ} \mathrm{C}$ and was identified as $\mathrm{S}$. saprophyticus subsp. saprophyticus (Figure 3) based on the 99.93\% sequence similarity to Staphylococcus saprophyticus subsp. saprophyticus ATCC $15305^{\mathrm{T}}$ (Hajek et al. 1996) for the $16 \mathrm{~S}$ rRNA gene sequence $(1,429 \mathrm{bp})$. Isolates FN6-1 and FN6-7also had circular and pale yellow colonies, but grew in $0-7 \%(\mathrm{w} / \mathrm{v}) \mathrm{NaCl}$, at $25-40^{\circ} \mathrm{C}$ and $\mathrm{pH} 5-9$ and $6-9$, respectively. They were both identified as $S$. saprophyticus subsp. bovis (Figure 3) from their 100 and 99.93\% sequence similarity to Staphylococcus saprophyticus subsp. bovis GTC $843^{\mathrm{T}}$ (Hajek et al. 1996) for the 16S rRNA gene (1,396 and $1,459 \mathrm{bp}$, respectively).
Thus, $V$. dokdonensis, O. iheyensis, $C$. variabile and $V$. halodenitrificans were isolated from Koey-pla (Mueang and Cha-uat district, Nakhon Si Thammarat province), B.amyloliquefaciens subsp. plantarum was isolated from Kee-dee (Mueang district, Nakhon Si Thammarat province) and $S$. saprophyticus subsp. bovis, S. saprophyticus subsp. saprophyticus and $V$. halodenitrificans were isolated from Tai-pla (Mueang district, Nakhon Si Thammarat province) (Table 1). The presence of extracellular lipolytic activity is consistent with previous reports for S. warneri BW 94 (Walavalkar \& Bapat 2001), Bacillus sp. BP-6 (Ruiz et al. 2003), Acinetobacter sp., Bacillus sp., Pseudomonas sp., Burkholderia sp., Proteus sp., Staphylococcus sp. (Gupta et al. 2004), Geobacillus sp. Tw1 (Li \& Zhang 2005), Haloarcula marismortui (Camacho et al. 2009), Bacillus sp. strain DVL2 (Kumar et al. 2012), B. mesenterichs, B. subtilis, B. cereus (Miettinen et al. 2013) and Idiomarina sp. W33 ( $\mathrm{Li}$ et al. 2014). These isolates may be involved in the changes in lipid composition during fermentation that enhance the flavor of the fermented fish products. This study is the first report on lipolytic Gram-positive bacteria

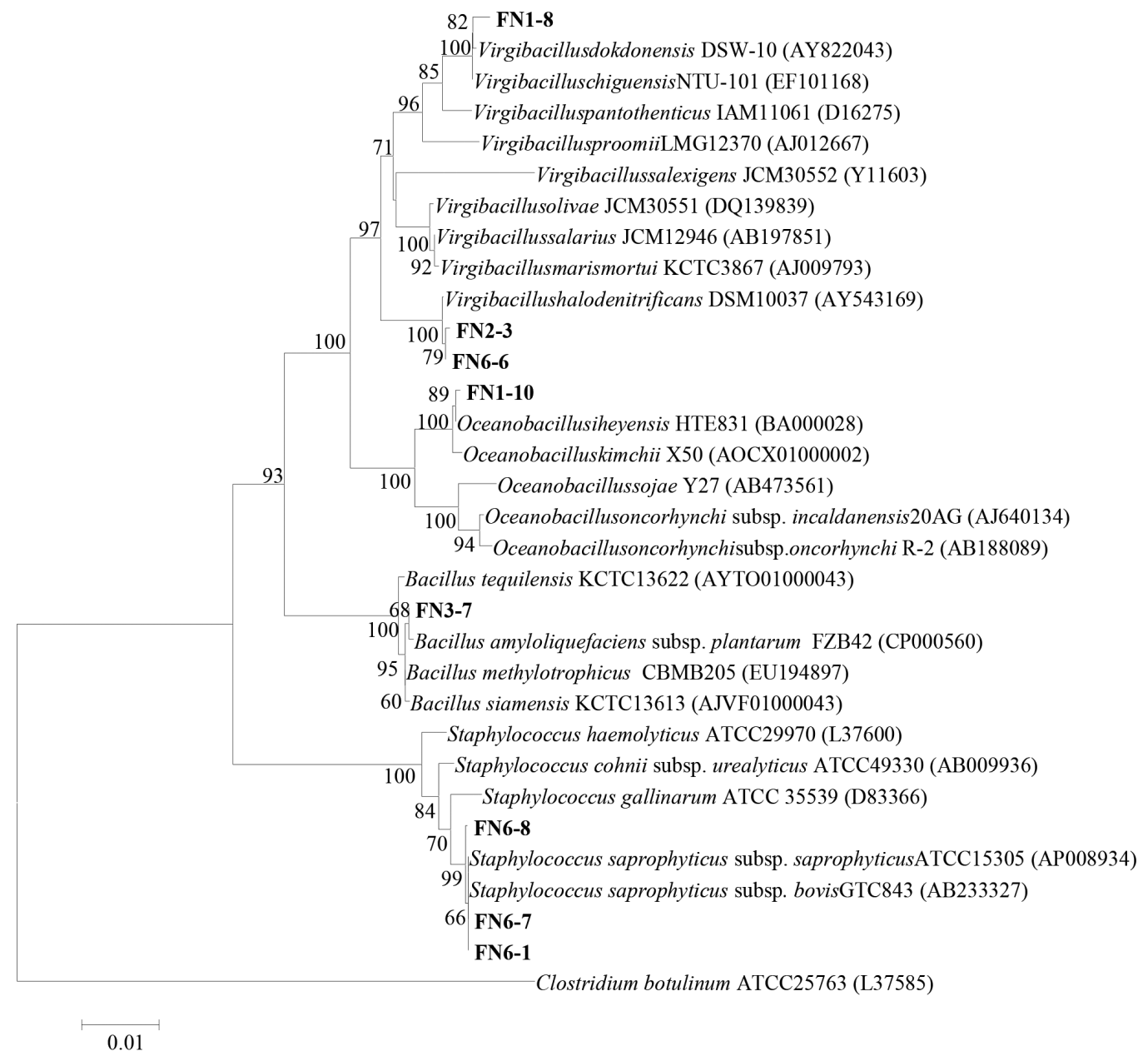

FIGURE 3. Neighbour-joining tree based on the 16S rRNA gene sequences showing relationships among Virgibacillus, Oceanobacillus, Bacillus and Staphylococcus isolates and related species. The numbers on the branches indicate the percentage bootstrap values of 1,000 replicates; only values $>50 \%$ are indicated. Bar, 0.01 substitutions per nucleotide position 
in the genera Bacillus, Corynebacterium, Oceanobacillus, Staphylococcus and Virgibacillus isolated from the Thai fermented fish products Koey-pla, Kee-dee and Tai-pla.

\section{CONCLUSION}

Nine lipolytic bacteria were isolated from Thai fermented fish products. They were identified as members of the Virgibacillus, Staphylococcus, Bacillus, Oceanobacillus and Corynebacterium genera based on their phenotypic characteristics, and from the $16 \mathrm{~S}$ rRNA gene sequence analyses (99.63-100\% sequence similarity) as $V$. dokdonensis, $V$. halodenitrificans, $O$. iheyensis, C. variabile isolated from fish paste (Koey-Pla), B.amyloliquefaciens subsp. plantarum strain from Kee-Dee and V.halodenitrificans, S. saprophyticus subsp. bovis and S. saprophyticus subsp. saprophyticus from Tai-Pla. The FN1-8 isolate, identified as $V$. dokdonensis, showed the highest lipase activity when cultivated in CM supplemented with $1 \%(\mathrm{v} / \mathrm{v})$ Tween 80.

\section{ACKNOWLEDGEMENTS}

This study was supported by the Thailand Research Fund for a 2012 Royal Golden Jubilee Scholarship as a research grant to R.D and the Grant for International Research Integration: Research Pyramid, Ratchadaphiseksomphot Endowment Fund (GCURP_58_01_33_01), Chulalongkorn University.

\section{REFERENCES}

Barrow, G.I. \& Feltham, R.K.A. 1993. Cowan and Steel's Manual for the Identification of Medical Bacteria. 3rd ed. Cambridge: Cambridge University Press. pp. 331.

Boutaiba, S., Bhatnagar, T., Hacene, H., Mitchell, D.A. \& Baratti, J.C. 2006. Preliminary characterization of a lipolytic activity from an extremely halophilic archaeon, Natronococcus sp. Journal of Molecular Catalysis B: Enzymatic 41: 21-26.

Camacho, R.M., Mateos, J.C., González-Reynoso, O., Prado, L.A. \& Córdova, J. 2009. Production and characterization of esterase and lipase from Haloarcula marismortui. Journal of Industrial Microbiology and Biotechnology 36: 901-909.

Chun, J., Lee, J., Jung, Y., Kim, M., Kim, S., Kim, B.J. \& Lim, Y. 2007. EzTaxon: A web based tool for the identification of prokaryotes based on 16 ribosomal RNA gene sequences. International Journal of Systematic and Evolutionary Microbiology 57: 2259-2261.

Collins, M.D. 1987. Transfer of Arthrobacter variabilis (Muller) to the Genus Corynebacterium, as Corynebacterium variabilis comb. nov. International Journal of Symstematic Bacteriology 37: 287-288.

Felsenstein, J. 1985. Confidence limits on phylogenies: An approach using the bootstrap. Evolution 39: 783-791.

Fukami, K., Ishiyama, S., Yaguramaki, H., Masuzawa, T., Nabeta, Y., Endo, K. \& Shimoda, M. 2002. Identification of distinctive volatile compounds in fish sauce. Journal of Agricultural and Food Chemistry 50: 5412-5416.

García-Lepe, R., Nuero, O.M., Reyes, F. \& Sanatamaría, F. 1997. Lipases in autolysed cultures of filamentous fungi. Letters in Applied Microbiology 25: 127-130.
Gayathri, V.R., Perumal, P., Mathew, L.P. \& Prakash, B. 2013. Screening and molecular characterization of extracellular lipase producing Bacillus species from coconut oil mill soil. International Journal of Science and Technology 2: 502-509.

Ghasemi, Y., Rasoul-Amini, S., Kazemi, A., Zarrini, G., Morowvat, M.H. \& Kargar, M. 2011. Isolation and characterization of some moderately halophilic bacteria with lipase activity. Microbiology 80: 483-487.

Gupta, R., Gupta, N. \& Rathi, P. 2004. Bacterial lipases: An overview of production, purification and biochemical properties. Applied Microbiology and Biotechnology 64: 763-781.

Hajek, V., Meugnier, H., Bes, M., Brun, Y., Fiedler, F., Chmela, Z., Lasne, Y., Fleurette, J. \& Freney, J. 1996. Staphylococcus saprophyticus subsp. bovis subsp. nov., isolated from bovine nostrils. International Journal of Systematic Bacteriology 46: 792-796.

Hasan, F., Shah, A.A. \& Hameed,A. 2006. Industrial applications of microbial lipases. Enzyme and Microbial Technology 39: 235-251.

Higaki, S. \& Morohashi, M. 2003. Propionibacterium acnes lipase in seborrheic dermatitis and other skin diseases and Unsei-in. Drugs under Experimental and Clinical Research 29: $157-159$.

Kumar, D., Kumar,L., Nagar, S., Raina, C., Parshad, R. \& Gupta, V.K. 2012. Screening, isolation and production of lipase/ esterase producing Bacillus sp. strain DVL2 and its potential evaluation in esterification and resolution reactions. Archives of Applied Science Research 4: 1763-1770.

Leifson, E. 1963. Determination of carbohydrate metabolism of marine bacteria. Journal of Bacteriology 85: 1183-1184.

Li,H.\& Zhang, X. 2005. Characterization of thermostable lipase from Thermophilic Geobacillus sp. TW1. Protein Expression and Purification 42: 153-159.

Li, X., Qian, P., Wu, S.G. \& Yu, H.Y. 2014. Characterization of an organic solvent-tolerant lipase from Idiomarina sp. W33 and its application for biodiesel production using Jatropha oil. Extremophiles 18: 171-178.

Lu, J., Nogi, Y. \& Takami, H. 2001. Oceanobacillus iheyensis gen. nov., sp. nov., a deep-sea extremely halotolerant and alkaliphilic species isolated from a depth of $1050 \mathrm{~m}$ on the Iheya Ridge. FEMS Microbiology Letters 205: 291-297.

Martin, S., Marquez, M.C., Sanchez-Porro, C., Mellado, E., Arahal, D.R. \& Ventosa, A. 2003. Marinobacter lipolyticus sp. nov., a novel moderate halophile with lipolytic activity. International Journal of Systematic and Evolutionary Microbiology 53: 1383-1387.

Miettinen, H., Nyyssölä,A., Rokka, S., Kontkanen, H. \& Kruus, K. 2013. Screening of microbes for lipases specific for saturated medium and long-chain fatty acids of milk fat. International Dairy Journal 32: 61-67.

Mrozik, A., Hubert-Kocurek, K. \& Łabużek, S. 2006. Lipases of genera Pseudomonas and Burkholderia and their applications in biotechnology. Postępy Mikrobiologii 45: 19-26.

Niazi, A., Manzoor, S., Bejai, S., Meijer, J. \& Bongcam-Rudloff, E. 2014. Complete genome sequence of a plant associated bacterium Bacillus amyloliquefaciens subsp. plantarum UCMB5033. Standards in Genome Sciences 9: 718-725.

Namwong, S., Tanasupawat, S., Smitinont, T., Visessanguan, W., Kudo, T. \& Itoh, T. 2005. Isolation of Lentibacillus juripiscarius sp.nov. from fish sauce in Thailand. International Journal of Systematic and Evolutionary Microbiology 55: 315-320. 
Noureddini, H., Gao, X. \& Philkana, R.S. 2005. Immobilized Pseudomonas cepacia lipase for biodiesel fuel production from soybean oil. Bioresource Technology 96: 769-777.

Ruiz, C., Javier Pastor, F. \& Diaz, P. 2003. Isolation and characterization of Bacillus sp. BP-6 LipA, a Ubiquitous lipase among mesophilic Bacillus species. Letters in Applied Microbiology 37: 354-359.

Saitou, N. \& Nei, M. 1987. The neighbor-joining method: Anew method for reconstructing phylogenetic trees. Molecular Biology and Evolution 4: 406-425.

Sharma, R., Christi, Y. \& Banerjee, U.C. 2001. Production, purification, characterization and application of lipases. Biotechnology Advances 19: 627-662.

Sirisha, E., Rajasekar, R. \& Lakshmi Narasu, M. 2010. Isolation and optimization of lipase producing bacteria from oil contaminated soils. Advances in Biological Research 4: 249-252.

Snellman, E.A., Sullivan, E.R. \& Colwell, R.R. 2002. Purification and properties of the extracellular lipase, LipA, of Acinetobacter sp. RAG-1. Federation of European Biochemical Societies 269: 5771-5779.

Tamura, K., Peterson, D., Peterson, N., Stecher, G., Nei, M. \& Kumar, S. 2011. MEGA5: Molecular evolutionary genetics analysis using maximum likelihood, evolutionary distance, and maximum parsimony methods. Molecular Biology and Evolution 28: 2731-2739.

Tanasupawat, S. \& Komagata, K. 2001. Lactic acid bacteria in fermented foods in Southeast Asia, in Microbial Diversity in Asia: Technology and Prospects, edited by B.H. Nga, H.M. Tan, and K. Suzuki). Singapore: World Scientific Publishing Co. Pte. Ltd. pp. 43-59.

Walavalkar, G.S. \& Bapat, M.M. 2001. Staphylococcus warneri BW 94 - A new source of lipase. Indian Journal of Experimental Biology 40: 1280-1284.

Yamada, Y., Katsura, K., Kawasaki, K., Widyastuti, Y., Saono, S., Seki, T., Uchimura, T. \& Komagata, K. 2000. Asaia bogorensis gen. nov., sp. nov., an unusual acetic acid bacterium in the $\alpha$-Proteobacteria. International Journal of Systematic and Evolutionary Microbiology 50: 823-829.
Yoon, J.H., Kang, S.J., Lee, S.Y., Lee, M.H. \& Oh, T.K. 2005 Virgibacillus dokdonensis sp. nov., isolated from a Korean island, Dokdo, located at the edge of the East Sea in Korea. International Journal of Systematic and Evolutionary Microbiology 55: 1833-1837.

Yoon, J.H., Oh, T.K. \& Park, Y.H. 2004. Transfer of Bacillus halodenitrificans Denariaz et al. 1989 to the genus Virgibacillus as Virgibacillus halodenitrificans comb. nov. International Journal of Systematic and Evolutionary Microbiology 54: 2163-2167.

Rungsima Daroonpunt \& Somboon Tanasupawat* Department of Biochemistry and Microbiology

Faculty of Pharmaceutical Sciences

Chulalongkorn University, Bangkok 10330

Thailand

Naoto Tanaka

NODAI Culture Collection Center (NRIC)

Faculty of Applied Bio-Science

Tokyo University of Agriculture

Tokyo 156-8502

Japan

Masataka Uchino

Department of Applied Biology and Technology

Faculty of Applied Bio-science

Tokyo University of Agriculture

Tokyo 156-8502

Japan

*Corresponding author; email: Somboon.T@chula.ac.th

Received: 10 August 2015

Accepted: 6 July 2017 